\title{
SOME NONLINEAR INTEGRAL INEQUALITIES AND THEIR DISCRETE ANALOGUES
}

\author{
WEIHONG SHENG AND WeI NiAn Li
}

Abstract. The purpose of this paper is to investigate some nonlinear integral inequalities and their discrete analogues. The inequalities given here can be used as handy tools in the qualitative theory of certain differential equations, integral equations and difference equations.

Mathematics subject classification (2010): 26D10, 26D15.

Keywords and phrases: Nonlinear integral inequality; nonlinear discrete inequality; differential equation; difference equation.

\section{REFERENCES}

[1] D. Bainov, P. Simeonov, Integral Inequalities and Applications, Kluwer Academic Publishers, Dordrecht, 1992.

[2] R. P. Agarwal, Difference Equations and Inequalities, Marcel Dekker Inc., New York, 1997.

[3] B. G. PACHPATte, Inequalities for Differential and Integral Equations, Academic Press, New York, 1998.

[4] B. G. PachPatte, Inequalities for Finite Difference Equations, Marcel Dekker Inc., New York, 2002.

[5] B. G. PACHPATTE, Integral and Finite Difference Inequalities and Applications, Elsevier Science B. V., Amsterdam, 2006.

[6] B. G. PACHPATTE, On some new inequalities related to a certain inequality arising in the theory of differential equation, J. Math. Anal. Appl. 251 (2000), 736-751.

[7] T. LÜ, Y. HUANG, A generalization of discrete Gronwall inequality and its application to weakly singular Volterra integral equation of the second kind, J. Math. Anal. Appl. 282 (2003), 56-62.

[8] W. SHENG, W. N. LI, Bounds on certain nonlinear discrete inequalities, J. Math. Inequal. 2 (2008), 279-286.

[9] K. Zheng, Y. Wu, S. Zhong, Discrete nonlinear integral inequalities in two variables and their applications, Appl. Math. Comput. 207 (2009), 140-147.

[10] Q. H. MA, J. PEČARIĆ, Explicit bounds on some new nonlinear retarded integral inequalities and their applicationsm, Taiwanese J. Math. 13 (2009), 287-306.

[11] W. N. LI, Some nonlinear integral inequalities in two independent variables, Advance in Difference Equations 2010 (2010), Artical ID 984141.

[12] W. N. LI, M. HAN, Bounds for certain nonlinear dynamic inequalities on time scales, Discrete Dynamics in Nature and Society 2009 (2009), Artical ID 897087. 